Revista de la red interuniversitaria de estudios sobre las literaturas rioplatenses contemporáneas en Francia

$18 \mid 2018$

El río y la ciudad

\title{
Penúltimas actividades
}

\section{Alejandro Zambra}

URL: http://journals.openedition.org/lirico/5178

DOI: $10.4000 /$ lirico.5178

ISSN: 2262-8339

Editor

Réseau interuniversitaire d'étude des littératures contemporaines du Río de la Plata

Referencia electrónica

Alejandro Zambra, « Penúltimas actividades », Cuadernos LIRICO [En línea], 18| 2018, Puesto en línea el 28 septiembre 2018, consultado el 02 mayo 2019. URL : http://journals.openedition.org/lirico/5178 ; DOI : 10.4000/lirico.5178

Este documento fue generado automáticamente el 2 mayo 2019.

\section{(c) $(1) \Theta \Theta$}

Cuadernos LIRICO está distribuido bajo una Licencia Creative Commons Atribución-NoComercialSinDerivar 4.0 Internacional. 


\title{
Penúltimas actividades
}

\author{
Alejandro Zambra
}

1. En un archivo de word, en un máximo de cinco mil caracteres con espacios, describe, con la mayor precisión posible, la casa en la que vives. Fíjate en especial en las paredes. Considera las grietas, las manchas, las huellas de clavos y perforaciones. Piensa, por ejemplo, en la cantidad de veces que esas paredes han sido pintadas. Imagina las brochas, los galones de pintura, los rodillos. Piensa en las personas que pintaron esas paredes. Evoca sus rostros, invéntalos.

Considera luego las goteras, las imperfecciones del suelo, las alfombras (si las hubiere), los cajones que no cierran del todo, los utensilios de cocina, el estado de las manillas y de los interruptores, la forma de los espejos (si los hubiere): pon especial atención a lo que los espejos reflejan cuando nadie los mira y recae sobre ellos la sospecha de su inutilidad.

2. Ordena los libros que haya en tu casa según su tamaño, pero no de mayor a menor, sino formando especies de olas o pirámides. No pienses, por favor, en la posibilidad de leerlos, no es ése el sentido de esta actividad. Tampoco te fijes en los títulos ni en los autores, enfrenta los libros como si fueran meros ladrillos imperfectos. Luego préndeles fuego y contempla las llamas desde una distancia prudente. Deja que el incendio crezca pero procura que no se vuelva incontrolable. Respira un poco de humo, cierra los ojos cada tanto, ojalá no más de diez segundos. Piensa esto: todo incendio, por leve o fugaz que sea, es un espectáculo. Piensa en las nubes cuando arden los árboles. Enseguida trata de extinguir el fuego, hazlo con serenidad y solvencia, en lo posible con elegancia. Finalmente mira al cielo, donde debería estar Dios o alguno de sus epígonos, y da las gracias.

Si pudiste controlar el incendio, si no estás, a estas alturas, muerto o a bordo de alguna ambulancia, si conseguiste -con o sin fe- dar las gracias a Dios o a alguno de sus epígonos, verás que hay libros carbonizados e irreconocibles, y otros a medio quemar, o casi completamente destruidos pero reconocibles, incluso legibles, y también un grupo de ejemplares casi intactos, quizás un poco mojados o tiznados, pero recuperables. Junta los libros arruinados, deposítalos en maletas que no uses con frecuencia o bien en bolsas reforzadas de basura, tamaño grande o gigante; camina hasta el río más cercano, arroja los bultos a la corriente, mira al cielo y da las gracias, pero esta vez sin mayor ceremonia, 
sin énfasis, con verdadera familiaridad hacia Dios o hacia sus epígonos o hacia la entidad que cumpla o debería cumplir una cierta función trascendente.

En el caso de que no hubiera un río razonablemente cercano, deja las bolsas en el lugar donde, si vivieras en otra ciudad, en una ciudad diseñada -bien o mal- por ti, debería haber un río. Quédate mirando la corriente, concéntrate en la corriente hasta que sientas que avanzas.

De vuelta en casa lee los libros que sobrevivieron al incendio y (a) saca tus conclusiones, no elabores demasiadas teorías, simplemente postula algunos sentidos, por abstrusos que sean, para el hecho justo o injusto pero siempre caprichoso de que hayan sido esos y no otros los libros salvados del incendio. Después (b) piensa, pero sin una gota de dramatismo ni de autocompasión, si esos libros podrían, de alguna manera, salvarte a ti.

3. Anota tus impresiones sobre la actividad número 2 en un archivo de word, tipografía Perpetua, tamaño 12, interlineado doble, y en un mínimo de cincuenta mil caracteres con espacios.

4. Repite la actividad número 2 hasta que no quede en tu casa ningún libro legible o reconocible. Da las gracias siempre, no hará falta que mires al cielo, solamente alza las cejas. Y concéntrate cada vez en el río, en la corriente (hasta que sientas que avanzas).

Luego, ya sin libros, empieza otro archivo. Escribe ahora sin restricciones de espacio, con la tipografía que más se parezca a tu propia letra, al recuerdo de tu propia letra manuscrita. Ahora sí escribe sobre tu vida: la infancia, el amor, el miedo. Y lo contrario del miedo, lo contrario del amor, lo contrario de la infancia. Y el hambre, la tos, todo eso. Haz memoria, no idealices pero tampoco evites la idealización. Si hablas sobre personas que alguna vez fueron cercanas pero ahora te parecen remotas, no teorices sobre la distancia; intenta comprender esa antigua cercanía. No evites los sentimentalismos, ni los gerundios.

Después selecciona todo el texto, cópialo en otro archivo, y borra a los personajes que sinceramente crees que habría sido mejor que nunca hubieran nacido, porque te hicieron daño a ti y/o a las personas que amas.

5. Junta todos los archivos en uno, en el orden que prefieras. La configuración de la página debe ser A5, el interlineado sencillo, la letra es opcional pero se sugiere Perpetua, tamaño 12. Enumera las páginas en posición inferior-derecha, busca un título, fírmalo con tu nombre o con un seudónimo o con el que crees que debería haber sido tu nombre, con el nombre que hubieras preferido tener. Sólo entonces, por primera vez, imprímelo todo y aníllalo. Has escrito un libro y esta vez no tienes que agradecérselo a nadie. Has escrito un libro, pero no lo publiques. Si quieres escribe otros y publícalos, pero ese libro no lo publiques nunca. 